\title{
PEMBUATAN DAN PENGECETAN TEMPAT SAMPAH
}

\section{RAHMIATI}

9173770410244

lavenderhime11@gmail.com

\section{Bentuk Kegiatan}

Pembuatan dan pengecetan tempat sampah

2. Lokasi

Rumah anggota PKK, Dusun pa'borongan Desa Bontocini Kecamatan Rumbia

3. Hari/Tanggal dan Waktu Jum'at, 02-10-2020 jam 16:06 dan dilanjut 20:41-selesai

4. Peserta yang Dilibatkan

- Mahasiswa KKLP

- Pemuda KArang Taruna Desa Bonocini

\section{Alasan Diadakannya}

Untuk menyelesaikan program kerja lebih cepat

\section{Referensi Wajib}

- HERIANTO, H., \& Amir, A. S. (2020, September 10). Pedoman Pelaksanaan Kuliah Kerja Lapangan Plus (KKLP) Mahasiswa STIE dan STKIP YAPTI Jeneponto. https://doi.org/10.31219/osf.io/7dvpk

\section{Tujuan dan Manfaat}

Tujuan dan manfaat pembuatan tempat sampah yaitu untuk menampung sampah yang ada di jalan dan pekarangan rumah masyarakat.

7. Produk Kegiatan (Jika Ada)

Tempat sampah

8. Deskripsi Kegiatan

Pembuatan di lakukan pada sore hari yang di bantu oleh pemuda karang taruna desa bontocini dan di lanjutkan pada malam hari sebagai proses pengecetan. 